\title{
Ethnobotany in a coastal environmental protected area: shifts in plant use in two communities in southern Brazil
}

\author{
Rafaela H. Ludwinsky* (D) and Natalia Hanazaki
}

\begin{abstract}
Background: We investigated local knowledge of plants in terms of plant use shifts and losses, in two coastal communities within a protected area in southern Brazil. Our hypothesis is that people's livelihoods are associated with different ethnobotanical knowledge, and changes in these activities can reflect shifts in ethnobotanical knowledge such as stopping using some plants.

Methods: We interviewed 125 inhabitants after prior informed consent, asking her/him about their socioeconomic profile and to free list the plants they know. The free lists were analyzed by frequency of cited plants. To compare averages of cited plants and age in both communities, we used the Wilcoxon test with a significance of 5\%. Spearman correlation was tested with number of plants cited in the past and the interviewees' age. Permanence and change in economic activities in each community were represented using a graph and compared through a chi-squared test with a significance of 5\%. Qualitative analyses of the interviews and a field diary were used to analyze driving forces for the abandonment of used plants.

Results: We identified 231 plant species that were currently used mainly for food and medicine. Despite being in a protected area, most of the cited plants were exotic and cultivated in home gardens. We do not confirm the hypothesis that changes in livelihoods are reflected in the plants used; however, qualitative analyses showed potential drivers for shifts and losses of plant use. "Environmental law" and "protected area" were the drivers most related to the abandonment of plant use.

Conclusions: While recognizing the importance of the protected area to maintain local people and their traditions, we documented a shift in plant use that is mainly correlated to construction activities that disappeared from daily practices.
\end{abstract}

Keywords: Brazilian atlantic forest, Shifts and losses in plant use, Coastal areas, Ethnobotany

\section{Background}

Coastal areas in tropical countries are rapidly changing due to tourism and urbanization [1]. The development of infrastructure and economic growth can transform coastal areas in a short period [2], and these transformations can influence local knowledge and practices, causing changes over time [2-6]. While urbanization and economic growth cause pressure on natural resources and local people, one strategy used to resist some of these changes is the creation of protected areas to conserve

${ }^{*}$ Correspondence: rafaela.hbio@gmail.com

Department of Ecology and Zoology, Laboratory of Human Ecology and

Ethnobotany, Federal University of Santa Catarina, Campus Reitor João David Ferreira Lima, Florianópolis 88040-900, Brazil remnants of nature in this complex scenario [7-9]. Protected areas fall under distinct categories of protection with different restrictions of use. One of the most flexible categories is category VI by the International Union for the Conservation of Nature [10], which allows human occupation and the sustainable use of natural resources, and in these cases, the conservation and use of natural resources must be combined to accomplish the goals of the protected area.

Ethnobotany can help explain how local people perceive, use, and manage plants [11]. Because ethnobotany investigates local knowledge through the body of local traditions and practices [12], it plays a key role in advancing our comprehension of possible knowledge responses 
driven by changes at a given point of time [13]. We investigated local knowledge of plants in terms of plant use shifts and losses, in two coastal communities within a protected area in southern Brazil. In doing so, we evaluate changes in economic activities as an influence on plant knowledge dynamics and discuss potential drivers of shifts in plant use that were mentioned by residents. Our hypothesis is that people's livelihoods are associated with different ethnobotanical knowledge, and changes in these activities can reflect shifts such as stopping using some plants. Our prediction is that in the communities with the highest proportion of change in livelihoods, there will be a higher frequency of citations of plants used in the past.

\section{Methods}

\section{Study area}

We conducted the study in the Anhatomirim Environmental Protected Area, in Governador Celso Ramos, Santa Catarina State, Southern Brazil. This coastal protected area was established in 1992 with the main purpose of conserving the Sotalia guianensis dolphin population in conjunction with the surrounding Atlantic Forest. The protected area is about 4436.56 ha and includes six communities [14], of which two were chosen for data collection: Areias de Baixo and Costeira da Armação (Fig. 1). The climate in this area is humid subtropical (Cfa), and the vegetation is ombrophilous dense forest.

These communities were chosen due to contrasting livelihoods of the inhabitants. Areias de Baixo comprises predominantly agricultural and gardening farmers who cultivate ornamental plants and crops for personal consumption. This community is partially within the protected area, and the part inside the area has about 115 inhabitants [15]. Costeira da Armação is completely within the protected area and has about 282 inhabitants [15] with a predominantly artisanal fishing economic profile. Additionally, Costeira da Armação is also known as

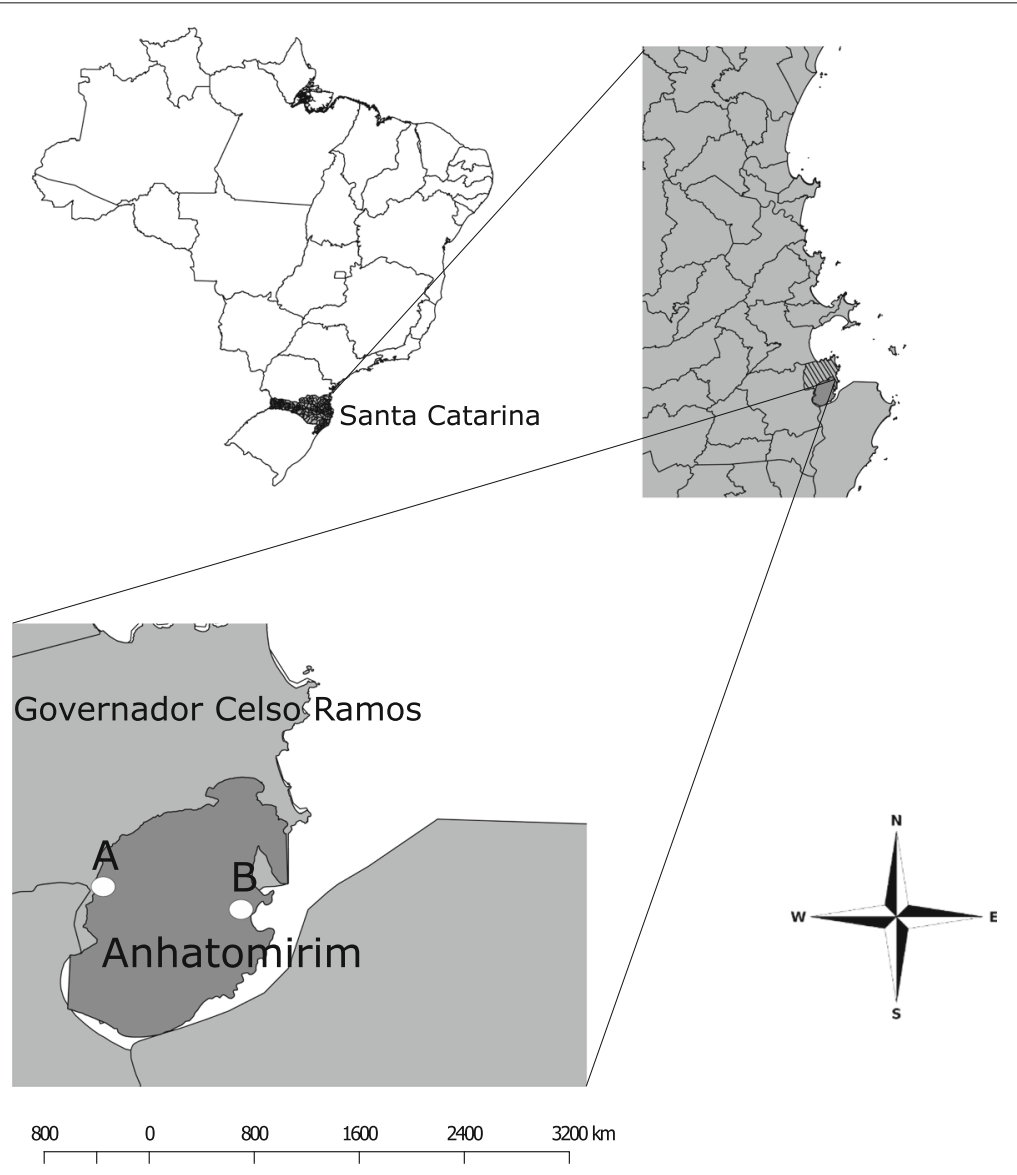

Legend
$\begin{aligned} & \text { Anhatomirim Environmental Protected Area A) Areias de Baixo and B) Costeira da Armação } \\ & \text { Santa Catarina and municipality of Governador Celso Ramos } \\ & \text { Brazil }\end{aligned}$

Fig. 1 Studied communities in the Anhatomirim Environmental Protected Area, in the municipality of Governador Celso Ramos, Santa Catarina, Brazil 
Baía dos Golfinhos (Dolphin's bay) due to its proximity to where dolphins (Sotalia guianensis) occur; thus, tourism is another important economic activity.

\section{Study design, data collection, and analysis}

We adopted the following criteria to include the collaborators in our sample: must be 18 years or older, a permanent resident or temporary resident for at least 5 years, and agree to participate in the research. We estimated the number of interviews according to [16]. This was based on the number of inhabitants of the communities, assumed an associated sampling error of $10 \%$ and resulted in 53 and 72 interviews for Areias de Baixo and Costeira da Armação, respectively. We conducted the interviews between November 2014 and June 2015.

We interviewed each collaborator separately. We asked about her/his socioeconomic profile, and we asked them to free list the plants they know. For each plant, we also asked about the purpose of use and we organized these purposes into categories, such as Food, Medicinal, Construction, Ornamental, and Others. Plants whose uses were cited only once or twice and for specific purposes, such as for handicrafts and superstitions, were placed in the last category (Others). We also asked about the situation of the use (present, past, or plants known but never used) and information about how they obtained the plants. We considered plants with past uses as those items used in the past, but currently not used. Plants known but never used were considered those plants which usefulness was learned about, but the interviewee did not actually use.

We collected and photographed the cited plants during walk-in-the-woods [17] in home gardens and areas of native vegetation. The plants were identified using literature [18-20] and had their names and origin checked with Tropicos [21] and Reflora [22] databases. Additionally, the first author kept a field diary to record notes with qualitative information.

We used descriptive statistics to analyze data from the interviews. Spearman correlation was tested with number of plants cited in the past and interviewees' age. The interviews of each community were used as a proxy to reflect different livelihoods; the main economic activity in Areias de Baixo is urban jobs, while in Costeira da Armação, it is artisanal fishing. To analyze changes in the knowledge and use of plants, we used a time span corresponding to the last 55 years, approximately, and this time span was determined in relation to childhood memories of the interviewees and to changes in environmental legislation and the establishment of the protected area.

Economic activities were organized into categories: City, Agriculture and fishing, Retired, and No income. Activities developed in the City category include those carried out in urban areas, such as small commerce of clothing or food and administrative activities in public and private companies. Permanence and change in economic activities in each community were compared through a chi-squared test with a significance of $5 \%$. For the free lists, we calculated the frequency of cited plants. To compare averages of age and number of cited plants in both communities, we used the Wilcoxon test with a significance of $5 \%$. Qualitative analyses of the interviews and of the field diary were used to analyze driving forces for the abandonment of plant use. To represent the dynamic in permanence and change in economic activities, we used the valued directed graph $G(V, A)$, where $V=\{v \in V \mid v$ is an occupation $\}$ and $A=$ $\left\{\left(v_{1}, v_{2}, n\right) \mid n\right.$ people that changed from occupation $v_{1}$ to occupation $\left.v_{2}\right\}$.

\section{Results}

Most of the interviewed residents were native to the research area (Areias de Baixo, hereafter $\mathrm{AB}=50.94 \%$, and Costeira da Armação CA $=69.44 \%$ ). The ages of the interviewees varied from 18 to 75 years old, and the average age was 48.03 years old $(\sigma=15.77)$ in $\mathrm{AB}$ and 52.62 years old $(\sigma=13.91)$ in CA. These averages were not significantly different $(W=1556, p$ value $=$ 0.07895). Comparative data of the sampling composition can be observed in the table (Table 1). The dynamics of

Table 1 Comparative table with socioeconomic characteristics of the studied communities

\begin{tabular}{|c|c|c|c|}
\hline & $\begin{array}{l}\text { Socioeconomic } \\
\text { characteristics }\end{array}$ & $\begin{array}{l}\text { Areias de Baixo (\%) } \\
(n=53)\end{array}$ & $\begin{array}{l}\text { Costeira da } \\
\text { Armação (\%) } \\
(n=72)\end{array}$ \\
\hline \multirow[t]{3}{*}{1.} & Gender & & \\
\hline & - Female & 58.49 & 45.84 \\
\hline & - Male & 41.51 & 54.16 \\
\hline \multirow[t]{3}{*}{2.} & Age & & \\
\hline & • 18-49 & 47.17 & 36.12 \\
\hline & • 50-75 & 52.83 & 63.88 \\
\hline \multirow[t]{5}{*}{3.} & $\begin{array}{l}\text { Economic activities in the } \\
\text { past }\end{array}$ & & \\
\hline & (a) Agriculture and fishing & 41.51 & 11.11 \\
\hline & (b) City & 24.53 & 18.06 \\
\hline & $\begin{array}{l}\text { (c) No changes in source of } \\
\text { income }\end{array}$ & 26.42 & 58.33 \\
\hline & (d) No income & 7.54 & 12.06 \\
\hline \multirow[t]{5}{*}{4.} & $\begin{array}{l}\text { Economic activities in the } \\
\text { present }\end{array}$ & & \\
\hline & (a) Agriculture and fishing & 13.20 & 37.5 \\
\hline & (b) City & 35.85 & 27.78 \\
\hline & (c) Retired & 13.20 & 15.28 \\
\hline & (d) No income & 37.75 & 19.44 \\
\hline \multirow[t]{3}{*}{5.} & Residence & & \\
\hline & $\begin{array}{l}\text { (a) Native from Governador } \\
\text { Celso Ramos }\end{array}$ & 50.94 & 69.44 \\
\hline & $\begin{array}{l}\text { (b) Native from other } \\
\text { municipalities }\end{array}$ & 49.06 & 30.56 \\
\hline
\end{tabular}


a

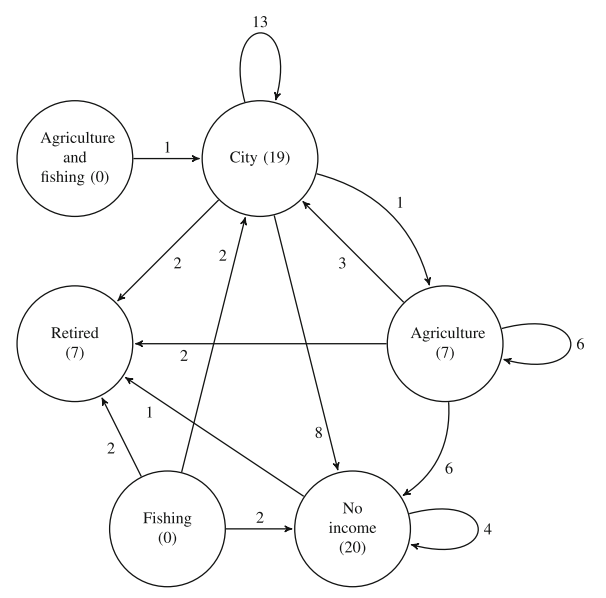

b

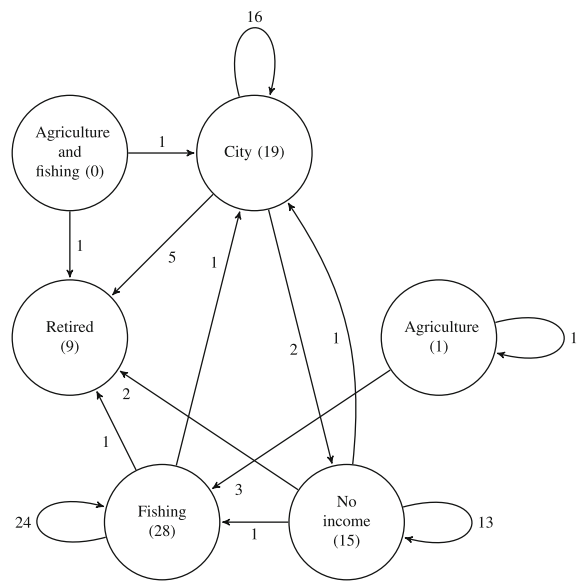

Fig. 2 Graph of the dynamics between permanence or change in economic activities of the interviewed residents: a Areias de Baixo and $\mathbf{b}$ Costeira da Armação. The number indicated in parentheses represents the total number of persons currently occupying the profession indicated at the vertex. The straight arrows indicate the changes in economic activities, and the loop arrows indicate the permanence in economic activity

permanence and change of the interviewees' economic activities (Fig. 2) show that about $13.2 \%$ of the interviewed residents from Areias de Baixo still work with agriculture, while about $36 \%$ of the interviewees from Costeira da Armação are still fishers, when compared to economic activities in the past. For permanence and change in the livelihoods, Areias de Baixo had a higher proportion of changes in economic activities compared to Costeira da Armação $\left(\chi^{2}=13.6017, p\right.$ value $\left.=0.000226\right)$.

\section{Diversity of plant knowledge}

We identified 231 plant species from 97 botanical families. The most representative families, in terms of number of species, were Asteraceae (20 species), Fabaceae (19), and Lamiaceae (16). For AB, the average number of cited plants (26.81, $\sigma$ 15.28) is higher than for CA $(17.25, \sigma 12.11)$, and these averages are statistically different (Wilcoxon $W=2763.5, p=1.916 \mathrm{e}-05$ ). The number of cited plants, category of use, and number of citations for each category are shown in Table 2 . In both communities,

Table 2 Number of plants cited by category of use and number of citations for each category of use according to 53 interviewees in Areias de Baixo and 72 in Costeira da Armação

\begin{tabular}{|c|c|c|c|c|}
\hline \multirow[b]{2}{*}{$\begin{array}{l}\text { Category } \\
\text { of use }\end{array}$} & \multicolumn{2}{|c|}{ Areias de Baixo $(n=53)$} & \multicolumn{2}{|c|}{ Costeira da Armação $(n=72)$} \\
\hline & $\begin{array}{l}\text { No. of } \\
\text { plants cited }\end{array}$ & $\begin{array}{l}\text { No. of } \\
\text { citations }\end{array}$ & $\begin{array}{l}\text { No. of } \\
\text { plants cited }\end{array}$ & $\begin{array}{l}\text { No. of } \\
\text { citations }\end{array}$ \\
\hline Food & 97 & 728 & 98 & 715 \\
\hline Medicinal & 51 & 299 & 55 & 280 \\
\hline Construction & 23 & 85 & 43 & 208 \\
\hline Ornamental & 61 & 247 & 20 & 29 \\
\hline Others & 16 & 51 & 13 & 38 \\
\hline
\end{tabular}

the food and medicinal categories are notable for having the most number of citations. The third most cited category was different in each community. In Areias de Baixo, it was ornamental plants, while in Costeira da Armação, it was plants for construction. The category Others (Table 2) includes plants used as handicrafts, such as Alchornea glandulosa Poepp. \& Endl. for making wooden clogs and Sansevieria trifasciata Prain as protection charms for houses.

In both communities, the most cited plant for food was Musa paradisiaca $\mathrm{L}$. and the most cited for medicine was Mentha rotundifolia (L.) Huds. As an ornamental plant, orchids (several species of Orchidaceae) was the most cited in Areias de Baixo. Schizolobium parahyba (Vell.) Blake was the most cited plant for the construction category in Costeira da Armação (Table 3). In Costeira da Armação, few species were cited as ornamentals, such as Portulaca grandiflora Hook., Mirabilis jalapa L., and Euphorbia pulcherrima Willd. ex Klotzsch, and all of them had low citation frequencies. In contrast, in Areias de Baixo, few species were cited for construction, such as Andira anthelmia (Vell.) J.F. Macbr., Copaifera trapezifolia Hayne, and Piptadenia gonoacantha (Mart.) J.F. Macbr, and all of them had low citation frequencies. The plants cited in both communities were strongly represented by exotic species $(\mathrm{AB}=74.40 \%, \mathrm{CA}=65.05 \%)$ (Table 3$)$.

\section{Use, management, and shifts in plant knowledge}

Most of the documented plants are still in use: about 90.44\% in Areias de Baixo and 76.08\% in the Costeira da Armação. Plants for food, medicine, and ornamental use had the most citations among the ones currently in use. In both communities, plants used in the past had $4.78 \%$ 


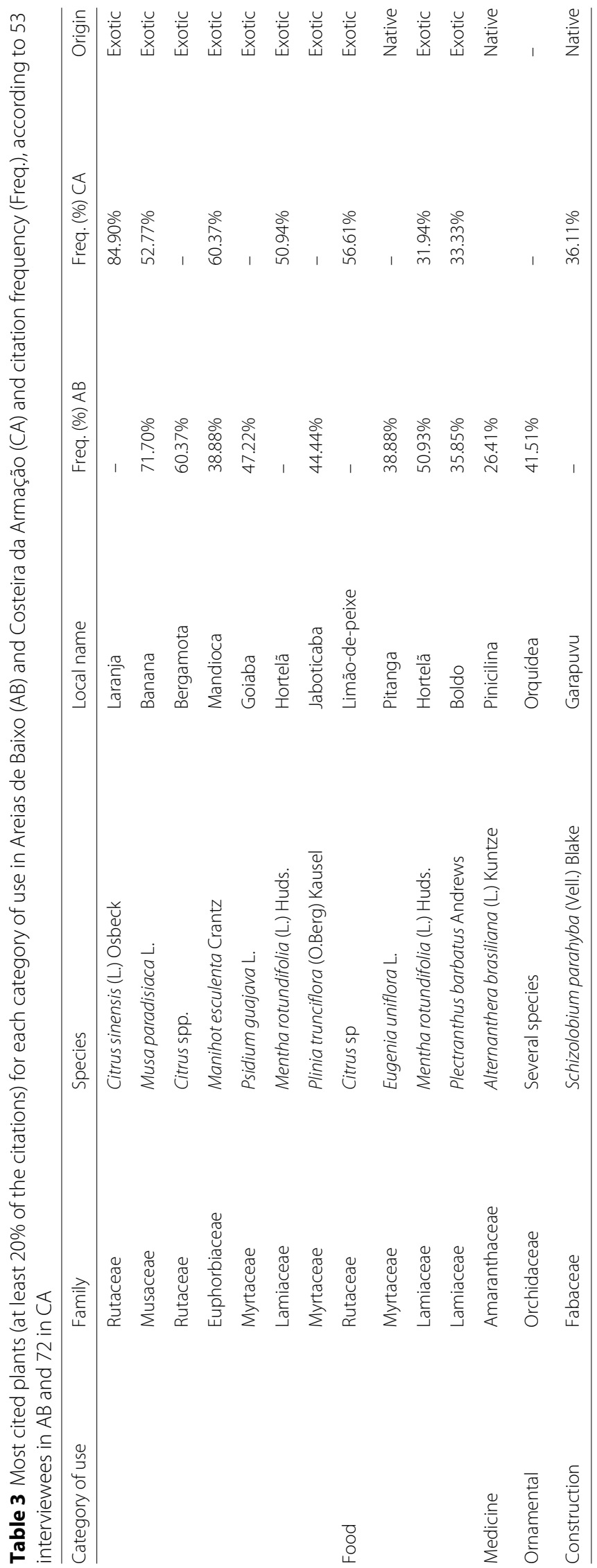


of citations in Areias de Baixo and $15.79 \%$ in Costeira da Armação. Plants cited as known but never used constituted $4.78 \%$ of the citations in Areias de Baixo and 8.13\% in Costeira da Armação. We noticed a contrasting result for the construction category between the communities. In Areias de Baixo, the plants used for construction were mostly cited as known but never used, while in Costeira da Armação, they were mostly cited due to their prior use (Fig. 3).

There was no correlation between age and number of plants cited in the past in both communities (AB Spearman correlation $=0.15$ and CA Spearman correlation $=$ 0.30 ). When asking about the plants used in the past, we found a set of memories related to childhood and another one related to daily practices. In Areias de Baixo, plants related to childhood include Inga sp. as a tree used to hang swings, Lagenaria spp. to make toys such as rattles, and Tanacetum vulgare L. as a medicine used during childhood.

In Costeira da Armação, plants used in the past were mainly cited as trees used to sustain swings and tree houses (Inga sp. and Hovenia dulcis Thunb.). We also recorded one plant used as food in the past, Momordica charantia L., and the use of this plant was followed by the explanation that it was considered a "poor people's food." For past uses, the interviewees also cited plants for daily practices, such as construction, repairs, and to make utensils for daily life. For example, Cupania vernalis Cambess. and Schizolobium parahyba (Vell.) Blake were both used to build canoes, and Piptadenia gonoacantha (Mart.) J.F. Macbr. was used to repair boats. Other uses of plants in the daily routine in the past included soap made from Aleurites fordii Hemsl and cleaning artifacts such as brooms (Baccharis sp.).

The most frequent places for obtaining plants (Fig. 4) were the following: backyards $(\mathrm{AB}=34.44 \%, \mathrm{CA}=$
28.82\%), markets $(\mathrm{AB}=25.16 \%, \mathrm{CA}=19.10 \%)$, forests $(\mathrm{CA}=18.75 \%)$, and neighbors' backyards $(\mathrm{AB}=11.59 \%$, $\mathrm{CA}=13.19 \%)$. Plants extracted from the forest $(\mathrm{AB}=$ $3.95 \%, \mathrm{CA}=5.73 \%$ ) were mostly fruits and medicinal herbs and were used as complementary resources to what was purchased at markets $(\mathrm{AB}=35.96 \%, \mathrm{CA}=33.04 \%)$ (Fig. 5).

\section{Discussion}

In our research, most of the recorded plants are still in use, which indicates the close proximity of the people to plants. However, the most important environments providing these plant resources are backyards, and not the forest. In other words, even considering that they live within or very close to a protected area created to conserve Atlantic Forest, the forest itself is little used. Larios et al. [23], in a study about plant management and biodiversity conservation in Náhuatl backyards in Mexico, found that even with surrounding forest, backyards compensate for the scarcity of naturally available plant resources. Such findings make backyards keystones in strategies for conservation. In spite that backyards have received increasing attention and are considered a conservation strategy of plant diversity at the local scale [24, 25], in the present study most taxa in the set of known plants are exotic. This set of exotic plants is used for food and medicine and some of the plants are also acquired in markets and serve as a complement to what is not easily obtained from gardens or during a certain season. A higher citation of exotic plants may be related to economic factors, such as agricultural activities that are based on exotic species in Brazil $[26,27]$. In addition, an explanation for the use of exotic medicinal plants could be versatility, specifically because these plants are used to treat many infirmities [28].

According to the interviews, the driving forces for shifts and losses of plants used in the past were (1) better options

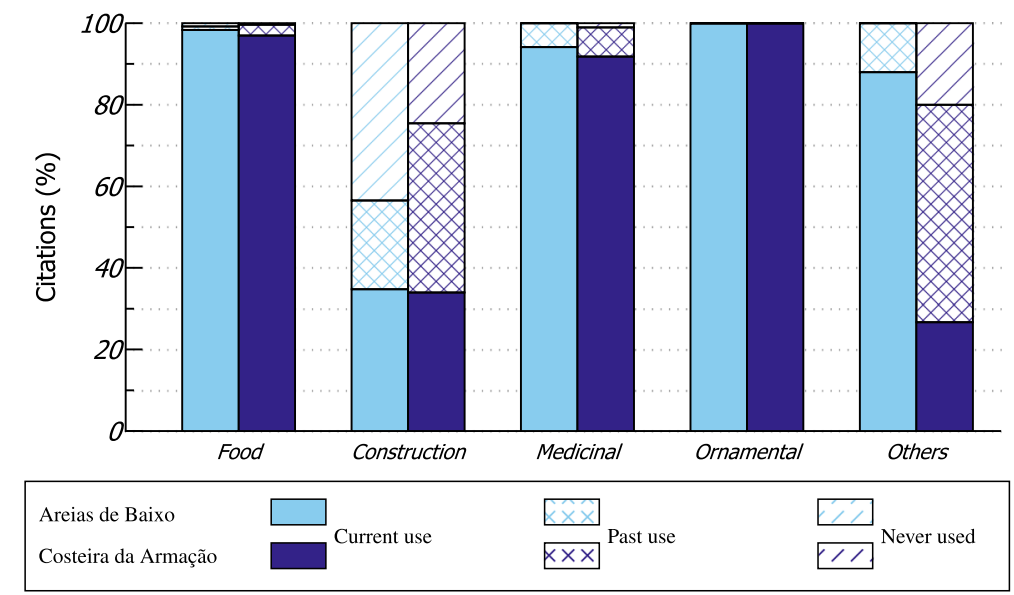

Fig. 3 Current and past use of plants cited in the interviews with 125 residents from Areias de Baixo and Costeira da Armação 


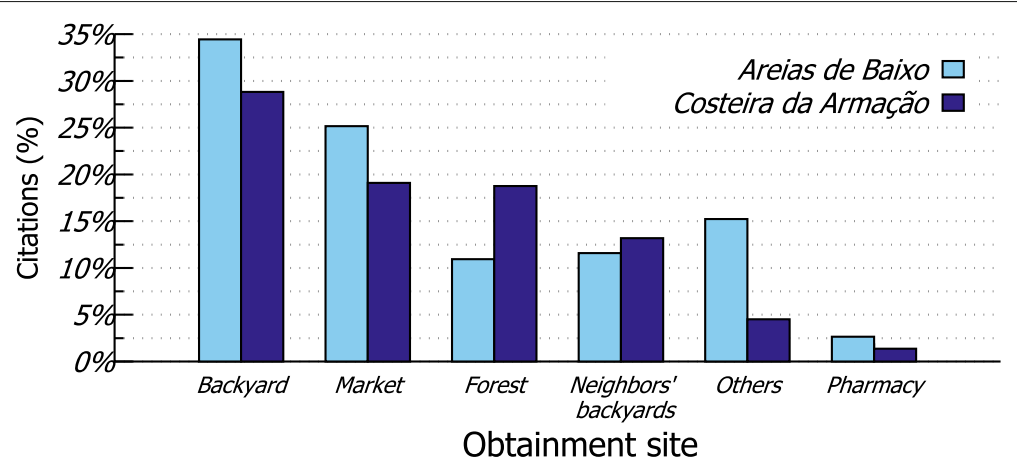

Fig. 4 Places for obtaining plants cited in the interviews with residents from Areias de Baixo $(n=302)$ and Costeira da Armação $(n=288)$

for the same purposes or, in some cases, they (2) replaced a plant by market products; (3) loss of interest in using a plant; (4) the current environmental law, which they quoted as "too restrictive"; and (5) the fact that they no longer find some plants (Fig. 6).

Besides food and medicine, ornamental was the most cited category by residents in Areias de Baixo because this community still has gardening and agricultural economic practices. On the other hand, plants for construction were most cited in Costeira da Armação due to fishing practices that require knowledge about canoe construction. However, unlike the ornamental category, plants used for construction refer to past uses. We noted that in both communities the age of interviewees was not correlated with number of plants cited in the past. The perception of plant use in the past may be associated with a variety of factors such as environmental legislation and the management rules of the protected area. Orofino et al. [29] report a decrease in access to timber resources for building and maintaining dugout canoes by artisanal fishers in Brazilian coastal areas of central Santa Catarina State. According to their study, artisanal fishers reported difficulties in access to trees and changes in fishing activities due to current legislation that does not allow the management of native species.
Ethnobotanical studies in coastal communities show that the socioeconomic profile of these areas varies through time, attracting new residents and developing different economic activities [2, 30,31]. There are several studies about the connection between socioeconomic changes and losses in ethnobotanical knowledge [3235]. Although our study found a greater proportion of livelihood changes in Areias de Baixo, we noted a lower frequency of cited plants with past uses for this community. On the other hand, for Costeira da Armação, we observed a lower proportion of livelihood changes and a higher frequency of plants cited with past uses. According to [36], this can be explained because changes in economic activities do not always lead to a loss of ethnobotanical knowledge if the activities keep people in their habitat and culture.

Qualitative analysis of the field diary discussions involved evaluating potential drivers of shifts and losses of plants reported by the collaborators interviewed. We distinguished a set of memories related to childhood and day to day activities. We call attention to the "environmental law" and "protected area" drivers related to the legislation protecting the Atlantic Forest (article 225 of the Brazilian Federal Constitution [37] and the decree 99547/90 [38]) and the creation of the Anhatomirim

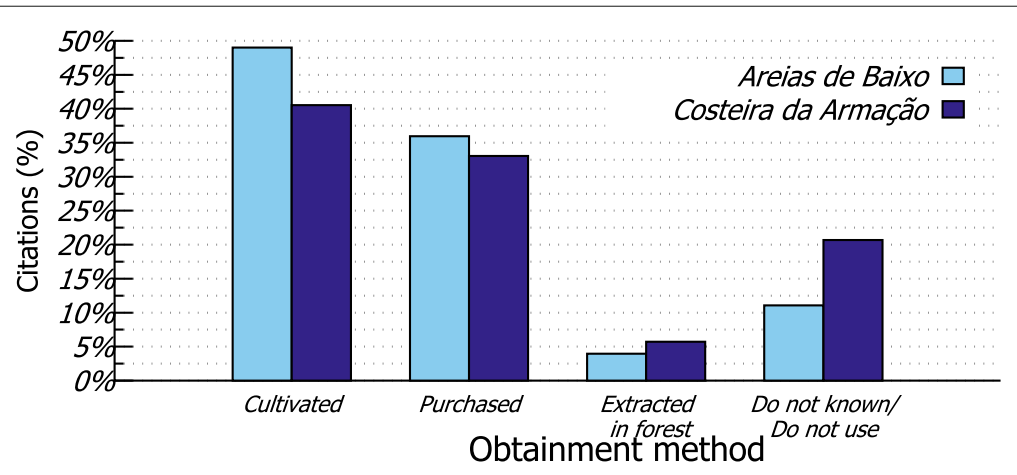

Fig. 5 Methods for obtaining plants cited in interviews with residents from Areias de Baixo $(n=253)$ and Costeira da Armação $(n=227)$ 


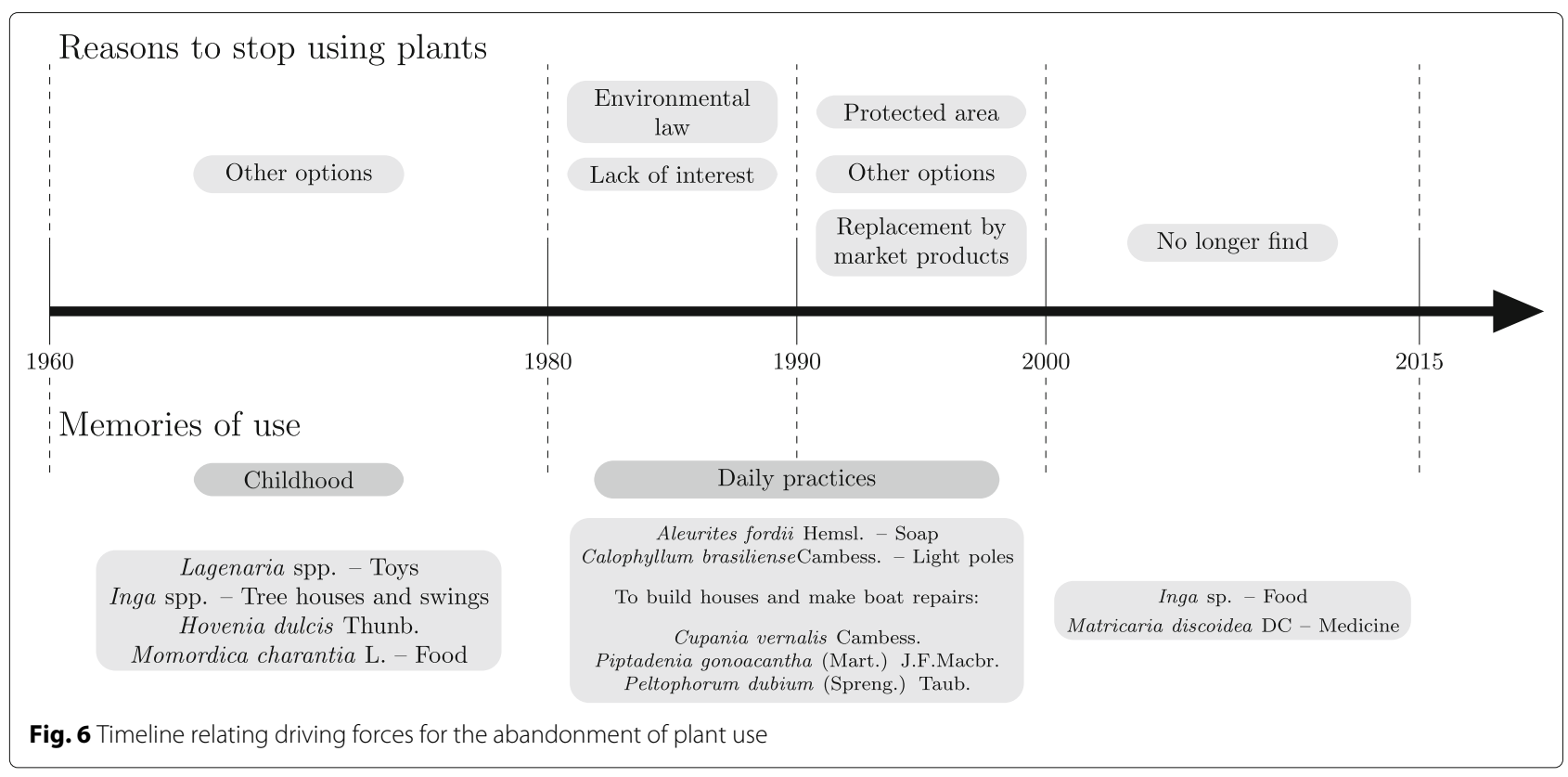

Environmental Protected Area, which forbids the cutting of native trees without permission. Since these communities are in an environmental protected area, residents were apprehensive when talking about plants used for construction because it would involve talking about timber plants that are mostly native. Therefore, the environmental law was also mentioned in justifying the abandonment of plants used in the past. This tendency in abandonment of plants and practices was also observed in studies by [29, 30, 39].

In some cases, residents mentioned the replacement by market products, such as commercial soaps replacing those usually made of Aleurites fordii Hemsl. The "lack of interest to keep using a plant" was another driving factor mentioned by some residents. Once they were no longer interested in being farmers or fishers, as their parents, they gradually stopped using some plants due to personal choice. According to [3], knowledge of plants may be threatened by external factors, such as cultural and economic pressure, since it is easier to access some plant resources by purchasing them. In a study on the knowledge and management of "restinga" plants in a local community in Brazil, [2] found that the frequency of plant use decreased considerably from past to present, which can cause loss of ethnobotanical knowledge among future generations.

\section{Conclusion}

Although the communities are close and located within the same environmental protection area, local knowledge about plants reveals particularities of the two communities. Qualitative analyses showed that while shifts in plant use seem to do more with personal choices and economic and market facilities, the loss of plant knowledge seems to be more related to drivers of environmental policies and the establishment of the protected area. We discard the hypothesis about changes in livelihoods and the reflection in plants used in the past, considering that even with changes in economic activities, ethnobotanical knowledge was embedded in the habitats and cultures of the collaborators interviewed. The maintenance of backyards can be a factor that favors ethnobotanical knowledge. Although our research has not assessed richness in backyards, the greater number of known exotic species in backyards requires further study before being used as an example for conservation strategies, especially in a protected area.

\section{Abbreviations}

AB: Areias de Baixo; CA: Costeira da Armação

\section{Acknowledgements}

We thank the communities for participating in the project and sharing their knowledge. We thank I. Zignani, J. Favaro, M. Pergher, T. Roque and T. Pagnoca for helping to collect data. We thank I. Seidel and G. Blanco for their suggestions about how to improve the manuscript and N. Smith for the english review.

\section{Funding}

This work was supported by the Brazilian Federal Agency for the Support and Evaluation of Graduate Education (CAPES) through the MSc scholarship awarded to RHL and by the Brazilian Council for Scientific and Technological Development (CNPq) through the research productivity grant awarded to $\mathrm{NH}$.

\section{Availability of data and materials}

Plants collected were deposited in the Federal University of Santa Catarina herbarium (FLOR), under the voucher numbers 0059283 to 0059285 , and the Federal Institute of Education, Science and Technology of Amazonas 
herbarium (EAFM), under the voucher numbers 16684 to 16701. Interview data, consent forms, and legal authorizations for interviews and plant collection are stored at the Laboratory of Human Ecology and Ethnobotany, Federal University of Santa Catarina, Brazil. All data generated or analyzed during this study are included in this article.

\section{Authors' contributions}

$\mathrm{RHL}$ and $\mathrm{NH}$ designed the study. RHL collected the data and analyzed the data. All authors contributed to the writing of the manuscript. All authors read and approved the final manuscript.

\section{Authors' information}

RHL is an MSc in Biology of Fungi, Algae and Plants (Federal University of Santa Catarina, Brazil). Her research interests involves changes in knowledge and use of plants through time. Contact:rafaela.hbio@gmail.com NH is a professor at Federal University of Santa Catarina, Brazil, Departament of Ecology and Zoology, ECOHE - Laboratory of Ethnobotany and Human Ecology. Main research interests are ethnoecology, traditional ecological knowledge, and conservation.Contact:natalia.hanazaki@ufsc.br

\section{Ethics approval and consent to participate}

This study was approved by the Ethics Committee of the State University of Santa Catarina (CEPSH, 35007214.4.0000.0118 at 11/11/2014), and the participation of the collaborators was conditional on free, prior, and informed consent. This study was also approved by the Brazilian System of Authorization and Information on Biodiversity (SISBIO, 44802-1 at 05/08/2014).

\section{Consent for publication}

Collaborators were informed that results would be presented in a scientific article and gave their approval.

\section{Competing interests}

The authors declare that they have no competing interests.

\section{Publisher's Note}

Springer Nature remains neutral with regard to jurisdictional claims in published maps and institutional affiliations.

\section{Received: 22 January 2018 Accepted: 11 October 2018}

Published online: 03 November 2018

\section{References}

1. Christie P, White TA. Trends in development of coastal area management in tropical countries: From central to community orientation. Coast Manag. 1997;25:155-81.

2. Gandolfo ES, Hanazaki N. Distribution of local plant knowledge in a recently urbanized area (campeche district, florianópolis brasil). Urban Ecosyst. 2014;17:775-85.

3. Amorozo DMMC. Uso e Diversidade de Plantas Medicinais em Santo Antônio do Laverger, MT, Brasil. Acta Botanica Brasilica. 2002;16:189-203.

4. Pieroni A, Vandebroek I. Traveling Cultures and Plants: the Ethnobiology and Ethnopharmacy of Human Migrations. New York: Berghahn; 2007.

5. Zank S, Hanazaki N. Exploring the links between ethnobotany, local therapeutic practices, and protected areas in santa catarina coastline, brazil. Evid Based Complement Alternat Med. 2012;2012:1-15.

6. Hanazaki N, Herbst DF, Marques MS, I. V. Evidence of the shifting baseline syndrome in ethnobotanical research. J Ethnobiol Ethnomedicine. 2013;9:75.

7. CBD. Convention on Biological Diversity. 1992. https://www.cbd.int/doc/ legal/cbd-en.pdf. Accessed 27 Aug 2017.

8. Hamú D, Auchincloss E, Goldstein W. Communicating protected areas, Commission on Education and Communication. 2004. https://portals. iucn.org/library/sites/library/files/documents/2004-057.pdf. Accessed 15 Sept 2017.

9. Dudley N, Higgins-Zogib L, Mansourian S. Beyond belief: linking faiths and protected areas to support biodiversity conservation. 2005. http:// d2ouvy59p0dg6k.cloudfront.net/downloads/beyondbelief.pdf. Accessed 15 Sept 2017.

10. Dudley N, Stolton S. Defining protected areas: an international conference in Almeria, Spain. 2008. https://portals.iucn.org/library/sites/ library/files/documents/2008-106.pdf. Accessed 14 Sept 2017.
11. Alcorn JB. The scope and aims of ethnobotany in a developing world. In: Shultes RE, von Reis S, editors. Ethnobotany: Evolution of a Discipline. Oregon: Dioscorides Press; 1995. p. 23-39.

12. Berkes F, Colding J, Folke C. Rediscovery of traditional ecological knowledge as adaptive management. Ecol Appl. 2000;10:1251-62.

13. Reyes-García V, Luz A, Gueze M, Paneque-Gálvez J, Macía M, Orta-Martínez M, Pino J. Secular trends on traditional ecological knowledge: An analysis of changes in different domains of knowledge among tsimane' men. Learn Individ Differ. 2013;27:206-12.

14. ICMBio. Área de Preseração Ambiental do Anhatomirim. Encarte 2 - Plano de Manejo. 2013. https://goo.gl/Z13DUk. Accessed 18 Sept 2017.

15. IBGE. Santa Catarina, Governador Celso Ramos - Síntese das Informações. 2010. http://goo.gl/4IWSjJ. Accessed 15 Mar 2017.

16. Barbetta PA. Estatística Aplicada às Ciências Sociais. Florianópolis: Ed. da UFSC; 2007.

17. Alexiades M. Selected guidelines for ethnobotanical research: a field manual. New York: The New York Botanical Garden; 1996.

18. Lorenzi H, Bacher L, Marco L, Sartori S. Frutas Brasileiras e Exóticas Cultivadas (de Consumo in Natura). São Paulo: Instituto Plantarum de Estudos da Flora; 2006.

19. Lorenzi H, Matos J. Plantas Medicinais No Brasil: Nativas e Exóticas. Nova Odessa: Instituto Plantarum de Estudos da Flora; 2008.

20. Sobral M, Jarenkow J, Brack P, Irgang B, Larocca J, Rodrigues R. Flora Arbórea e Arborescente do Rio Grande do Sul, Brasil. São Carlos: RiMa Editora; 2013.

21. Tropicos.org. Missouri Botanical Garden. http://www.tropicos.org.

22. Jardim Botânico do Rio de Janeiro. http://floradobrasil.jbrj.gov.br/.

23. Larios C, Casas A, Vallejo M, Moreno-Calles Al, Blancas J. Plant management and biodiversity conservation in náhuatl homegardens of the tehuacán valley, mexico. J Ethnobiol Ethnomedicine. 2013;9:74.

24. Albuquerque UP, Andrade LHC, Caballero J. Structure and floristics of homegardens in northeastern brazil. J Arid Environ. 2005;65:491-506.

25. Gbedomon R, Salako V, Adomou A, Kakaï R, Assogbadjo A. Plants in traditional home gardens: richness, composition, conservation and implications for native biodiversity in benin. Biodivers Conserv. 2017;26: 3307-327.

26. Dehnen-Schmutz K, Touza J, Perrings C, Williamson M. A century of the ornamental plant trade and its impact on invasion success. Divers Distrib. 2007; 13:527-34.

27. Coradin L, Siminski A, Reis A. Espécies Nativas da Flora Brasileira de Valor Econômico Atual ou Potencial: Plantas para o Futuro - Região Sul. 2011. https://goo.gl/R5eSN2. Accessed 15 June 2017.

28. Albuquerque $U$. Re-examining hypotheses concerning the use and knowledge of medicinal plants: a study in the caatinga vegetation of ne brazil. J Ethnobiol Ethnomedicine. 2006;2:30.

29. Orofino G, Roque T, Kruel V, Peroni N, Hanazaki N. Local knowledge about dugout canoes reveals connections between forests and fisheries. Environ Dev Sustain. 2017:10-10071066801700168.

30. Turner N, Turner K. Where our women used to get the food: cumulative effects and loss of ethnobotanical knowledge and practice; case study from coastal british columbia. Botany. 2008;86:103-15.

31. Giraldi M, Hanazaki N. Uso e conhecimento tradicional de plantas medicinais no sertão do ribeirão, florianópolis, sc, brasil. Acta Botanica Brasilica. 2010;24:395-406.

32. Godoy R, Brokaw N, Wilkie D, Colón D, Palermo A, Lye S, Wei S. Of trade and cognition: Markets and the loss of folk knowledge among the tawahka indians of the honduran rain forest. J Anthropol Res. 1998;54: 219-33.

33. Reyes-García V, Vadez V, Byron E, Apaza L, Leonard W, PerezE, Wilkie D Market economy and the loss of folk knowledge of plant uses: Estimates from the tsimane' of the bolivian amazon. Curr Anthropol. 2005;46:651-6.

34. Saynes-Vásquez A, Caballero J, Meave J, Chiang F. Cultural change and loss of ethnoecological knowledge among the isthmus zapotecs of mexico. J Ethnobiol Ethnomedicine. 2013;9:40.

35. Beltrán-Rodríguez L, Ortiz-Sánchez A, Mariano N, Maldonado-Almanza B, Reyes-García V. Factors affecting ethnobotanical knowledge in a mestizo community of the sierra de huautla biosphere reserve, mexico. J Ethnobiol Ethnomedicine. 2014;10:14.

36. Reyes-García V, Vadez V, Tanner S, McDade T, Huanca T, Leonard W. Evaluating indices of traditional ecological knowledge: a methodological contribution. J Ethnobiol Ethnomedicine. 2006;2:21. 
37. BRASIL. Art. 225 da Constituição Federal Brasileira de 1988. Brasília, 5 de outubro de 1988, Brasília. 1988. http://www.planalto.gov.br/ccivil_03/ constituicao/constituicaocompilado.htm. Accessed 20 Jan 2017.

38. BRASIL. Decreto $n^{\circ} 99.547$, de 25 de Setembro de 1990. Diário Oficial da União 25 de Setembro de 1990, Brasília. 1990. http://www2.camara.leg. br/legin/fed/decret/1990/decreto-99547-25-setembro-1990-339012publicacaooriginal-1-pe.html. Accessed 20 Jan 2017.

39. Andrade I, Lucena E, Chiapetti J, Pereira R, Mielke M. Espécies arbóreas utilizadas por pescadores para a construção de jangadas, Área de proteção ambiental costa de itacaré-serra grande, bahia, brasil. Rodriguésia. 2016;67:45-53.

- fast, convenient online submission

- thorough peer review by experienced researchers in your field

- rapid publication on acceptance

- support for research data, including large and complex data types

- gold Open Access which fosters wider collaboration and increased citations

- maximum visibility for your research: over $100 \mathrm{M}$ website views per year

At $B M C$, research is always in progress.

Learn more biomedcentral.com/submissions 